\title{
The Impact of Modernizing Transformations on the Development of the Education System of the Steppe Region and Turkestan in the 1880s-1910s
}

\section{Maria V. Rygalova}

Polzunov Altai State Technical University. Barnaul, Russia. Email: mariya_rygalova[at]mail.ru

\section{Abstract}

The Central Asian region of the Russian Empire in the second half of the 19th - early 20th centuries is of interest from the point of view of modernizing transformations, which had specifics in connection with the geographical location, the composition of the population, the position within the Empire. Traditionally, modernization is considered as a set of indicators, primarily as a transition from an agrarian system to an industrial one. However, researchers highlight the socio-cultural context of modernization, including the education system. It is sometimes attributed to the spiritual aspect of modernization. Education, as a modernization indicator, is secondary, but it is associated with many socio-economic factors. The purpose of the study is to analyze the development of the education system of the Central Asian region of the Russian Empire in the context of modernizing transformations. As a result of the study, it was found out that the Russian authorities sought to systematically modernize the outlying territories. This can be seen in the example of the reorganization of the network of educational institutions. In particular, the formation of the education system for the indigenous population of the Steppe Region and Turkestan was thoughtful, with a focus on trends in changes in traditional society, in the context of socio-economic transformations, including the agricultural and industrial sectors of the economy. The article may be of interest to specialists studying the Central Asian region of the Russian Empire, as well as the development of the Russian education system.

\section{Keywords}

Modernization; Central Asian Region of the Russian Empire; Steppe Region; Turkestan; Education System; a Network of Educational Institutions; Professional Education; Russian-Kazakh Schools; Aul Schools; Foreign Population

This work is licensed under a Creative Commons "Attribution" 4.0 International License 


\section{Влияние модернизационных преобразований на развитие системы образования Степного края и Туркестана в 1880 - 1910-е гг.}

\section{Рыгалова Мария Владимировна}

Алтайский государственный технический университет им. И. И. Ползунова. Барнаул, Россия. Email: mariya_rygalova[at]mail.ru

\section{Аннотация}

Центральноазиатский регион Российской империи второй половины XIX - начала XX вв. представляет интерес с точки зрения модернизационных преобразований, которые имели специфику в связи с географическим положением, составом населения, положением в составе империи. Традиционно модернизацию рассматривают с точки зрения разных показателей, прежде всего, в контексте перехода от аграрного строя к индустриальному. Однако исследователи выделяют социокультурный контекст модернизации, в том числе систему образования, иногда относя его к духовному аспекту модернизации. Образование, как модернизационный показатель, является второстепенным, однако связанным со многими социально-экономическими факторами. Цель исследования - анализ развития системы образования центральноазиатского региона Российской империи в контексте модернизационных преобразований.

В результате исследования установлено, что российские власти стремились к планомерной модернизации окраинных территорий, что видно, в том числе, на примере реорганизации сети образовательных учреждений. В частности, выстраивание системы образования для коренного населения Степного края и Туркестана носило продуманный характер, с ориентацией на тенденции к изменениям традиционного общества, в контексте социально-экономических преобразований, в том числе в аграрном и индустриальном секторах экономики. Статья может быть интересна специалистам, изучающим центральноазиатский регион Российской империи, а также развитие системы образования России.

\section{Ключевые слова}

модернизация; центральноазиатский регион Российской империи; Степной край; Туркестан; система образования; сеть образовательных учреждений; профессиональное образование; русско-казахские школы; аульные школы; инородческое население

Это произведение доступно по лицензии Creative Commons “Attribution” («Атрибуция») 4.0 Всемирная 


\section{Введение}

Модернизация в Российской империи во второй половине XIX в. затронула различные стороны развития страны, не оставив в стороне недавно присоединенные территории азиатских окраин. Однако специфика исторического развития, традиции, культура окраинных территорий, в частности, Степного края и Туркестана, имели в этом процессе особенности, присущие им. Кроме того, в современной науке при обращении к вопросам модернизации принято делать акцент, в том числе, на географическом факторе, который оказывает влияние на общественное развитие (Бородкин, 2017). В данном исследовании под модернизацией понимаются изменения, которые имеют отношение к различным направлениям и уровням общественного развития, распространяются как на отдельные сферы, так и на перестройку социокультурной системы в целом (Южакова, 2006).

Подавляющее большинство населения Туркестана и Степного края до присоединения к Российской империи вело кочевой образ жизни, занималось скотоводством, являлось мусульманами по вероисповеданию. Перед российскими властями остро стояла проблема интеграции окраин в общеимперское пространство, с которой предстояло справиться, чтобы не допустить усиления национального компонента в Степном крае и Туркестане. С этой целью власти активно предпринимают попытки распространения русского языка, культуры и православия среди коренного населения азиатских окраин. Центральную роль в этом процессе играли учебные заведения, которым уделялось пристальное внимание. Кроме того, на русских переселенцев возлагались задачи привнесения и распространения среди кочевого населения оседлого образа жизни, земледелия, а также в целом разбавления инородческого населения русскими с целью недопущения усиления национального единства мусульман. В свою очередь, это позволяло решать сразу несколько важных для государства задач, в частности, малоземелье центральной России, развитие хлопководчества на благоприятных для возделывания этой культуры полях Туркестана, освоение пустующих земель Степного края (Котюкова, 2015, с. 45-49). Эти процессы протекали на фоне общероссийской модернизации, которая постепенно приходит и на окраинные территории Российской империи.

Целью исследования является анализ развития системы образования центральноазиатского региона Российской империи в контексте модернизационных преобразований.

Территориальные рамки исследования включают девять областей Степного края и Туркестана: Акмолинскую, Закаспийскую, Самаркандскую, Семипалатинскую, Семиреченскую, Сыр-Дарьинскую, Тургайскую, Уральскую, Ферганскую. 
Хронологические рамки охватывают 1885-1917 гг., что обусловлено оформлением Туркестанского генерал-губернаторства в 1867 г. и Степного края в 1882 г., а также складывающимися модернизационными изменениями, которые в регионе начинают протекать в отличие от центральной России несколько позднее.

Основным источником исследования послужили статистические обзоры областей - как самостоятельное издание или как приложение к ежегодным отчетам губернаторов. Источник включает в себя исчерпывающую информацию о развитии и жизнедеятельности областей по основным направлениям развития (природа, географическое положение, население, сельское хозяйство, промышленность, налоги, торговля, медицина, образование и проч.) Обзоры состоят из описательной и статистической информации. Несмотря на отличия, иногда существенные, в структуре и степени подробности опубликованных данных, преимущество источника заключается в четкой периодичности (обзоры издавались ежегодно), комплексности сведений (по многим отраслям), доступности источника (большая часть обзоров доступна в оцифрованном виде на сайте Государственной публичной исторической библиотеки России). Исследователи в области источниковедения называют обзоры ценным источником данных (Ковальченко, 1959; Литвак, 1976, с. 144).

\section{Образовательная политика в Центральноазиатском регионе}

В связи с включением территорий Степного края и Туркестана в состав Российской империи государством начинает осуществляться целенаправленная политика адаптации инородцев к русскому языку и культуре. Главным проводником этого процесса должны были стать государственные школы. Российские власти рассматривали распространение русского языка среди населения окраин как главный фактор модернизационных преобразований (Лысенко, 2011, с. 119-120). В свою очередь, русификация способствовала распространению уровня образования, увеличению социальной мобильности населения (Лысенко и др., 2014, с. 16).

Первый генерал-губернатор Туркестана К.П. Кауфман отмечал, что сложившаяся система образования была достаточно крепкой и сильной для проживающего на территории населения; именно с ней и предстояло бороться в связи с распространением системы русских школ, которым со второй половины XIX в. российские власти уделяли большое внимание как движущей силе модернизации и распространения русского языка в регионе (Кауфман, 1885, с. 429-432).

Русским языком казахи владели слабо; например, из 35 письмоводителей при волостном управлении в Тургайской области в 1870-е гг. не было ни одного казаха. Из 645 должностных лиц общественного киргизского управления лишь 
18 владели русским языком, из 74530 человек Иргизского уезда лишь 11 знали русский язык (Обзор Тургайской..., 1879, с. 16-19). Низкий уровень владения русским языком среди местного населения, в том числе занимающего административные должности, не только затруднял деятельность в сфере управления на подконтрольных российской власти территориях, но и никак не мог способствовать реализации целей российского правительства в распространении русского языка и последующей интеграции в общеимперское пространство (Любичанковский, 2018, с. 162).

Русский язык являлся официальным языком делопроизводства на окраинах империи. К кандидатам на должности предъявлялось требование знания русского языка (Лысенко и др., 2021, с. 155-156). Долгое время российские власти не предпринимали жестких мер по распространению русского языка, однако с 1906 г. он стал обязательным в этноконфессиональных школах (Инородческая школа..., 1916, с. 146-147).

Складывание системы образования было неотъемлемым фактором модернизационных преобразований, которые происходили в обществе во второй половине XIX в. в России, и которые начинают постепенно приходить на территорию азиатских окраин империи с 1880-х гг. В изменившихся условиях после присоединения территорий встают насущные задачи использования их ресурсного потенциала, прежде всего, в сфере сельского хозяйства. Еще одной взаимосвязанной причиной поиска новых путей развития и адаптации к изменившимся условиям становится крестьянская колонизация Степного края и Туркестана конца XIX-начала XX вв., существенно изменившая структуру населения в сторону увеличения числа русских. Переселение крестьян на свободные земли и разбавление этнического состава местного населения способствовало значительным изменениям в различных сферах общественного развития в связи с необходимостью освоения потенциала земельных и промышленных ресурсов. Модернизация в России требовала освоения и привлечения новых ресурсов, в том числе Туркестана и Степного края.

Изменения в развитии страны сказались и на формировании системы образования в регионе. Российские власти рассматривали русское население как потенциал для усиления процессов обрусения и распространения русского языка среди жителей окраинных территорий (Ремнев, 2013, с. 78). Рост территории за счет русского населения привел к необходимости выстраивания системы образования, которая должна была работать на усиление тенденций модернизации и выстраивание консолидации жителей окраин и русских переселенцев, которых в конце XIX-начале XX вв. за счет крестьянской колонизации становилось все больше (Бекмаханова, 1986, с. 203). В этой связи министерство народного просвещения было заинтересовано в скорейшем формировании сети школ в Степном крае и Туркестане как для русского, так и для коренного населения. Она состояла из одно-двух-, реже трех- и четырех- 
классных начальных училищ в городах, сельских училищ в уездах, в которых можно было получить начальное образование, гимназий и прогимназий для мальчиков и девочек для перехода на следующую ступень образования. Согласно уставу гимназий и прогимназий и положению о народных училищах, провозглашался всесословный принцип обучения (Положение..., 1864, с. 614). Эти учебные заведения находились в ведении министерства народного просвещения. В Туркестане первая школа для русских детей была открыта в 1866 г. После образования Туркестанского генерал-губернаторства в 1867 г. русские школы стали открываться в каждом городе, а затем и в сельской местности (Бендриков, 1960, с. 61).

В связи с выходом правил о церковно-приходских школах начинается их массовая организация (Правила..., 1884, с. 372). Они подразделялись на одно- и двухклассные, в небольших населенных пунктах открывались школы грамоты. Из отчета о состоянии Омской епархии за 1902 г. следует, что церковноприходские школы пользовались в обществе спросом и интересом, они строились и содержались часто на частные пожертвования (Отчет..., 2014, с. 449). Учащимися этих школ были русские крестьяне.

Согласно Временному положению об Управлении в областях Уральской, Тургайской, Акмолинской и Семипалатинской 1868 г. устанавливались основные принципы развития образования окраинных территорий. В каждом уезде должна была быть открыта школа для всех народностей, регулирование образования возлагалось на генерал-губернатора. Мусульманские школы при мечетях могли быть открыты с разрешения уездного начальства. Надзор за соблюдением всех образовательных требований осуществляло Министерство народного просвещения (Временное...).

В 1904 г. обсуждалось введение всеобщего обучения для детей русских крестьян в Туркестане. В Закаспийской области военный губернатор Куропаткин издал распоряжение о штрафах за уклонение по неуважительной причине от обучения (Туркестанские ведомости, 1898, с. 2). Таким образом, власти стремились воздействовать на ускорение процессов распространения русского языка.

На рубеже XIX-XX вв. мусульманские школы не отвечали запросам по уровню образования. Знаний, полученных в школах, было недостаточно для жизни, их невозможно было использовать в повседневной практике (Доклад..., 1870, с. 228-229). Вместе с тем российские власти понимали устойчивость мусульманского традиционного образования, поэтому попытки его замены были постепенными и продуманными.

Для распространения русского языка среди казахского и коренного туркестанского населения российские власти создают сеть русско-казахских и аульных школ в Степном крае и русско-туземных в Туркестане. Эти школы рассматривались как альтернатива мусульманскому образованию, основанному на религиозном принципе и оторванному от практической жизни. К тому 
же как основу модернизации российские власти рассматривали русский язык. На рисунках 1-2 в качестве примера показан рост количества учащихся в русско-казахских и аульных школах. Видно, что к началу ХХ в. численность обучающихся в них возрастает, что было связано непосредственно как с ростом населения в регионе за счет переселенцев, так и с меняющимися условиями жизни в контексте социально-экономических преобразований. Таким образом, все больше населения было задействовано в сфере начального образования. К тому же развитие капиталистических отношений во второй половине XIX в. требовало участия в социально-экономических процессах образованных людей, владеющих русским языком и грамотой, а также профессиональными умениями в области торговли, техники, сельского хозяйства. Однако для поступления в профессиональные школы, сеть которых в азиатском регионе также начинает формироваться вслед за социально-экономическими преобразованиями, необходим был начальный уровень образования. Это делало русско-казахские, аульные и русско-туземные школы более востребованными.

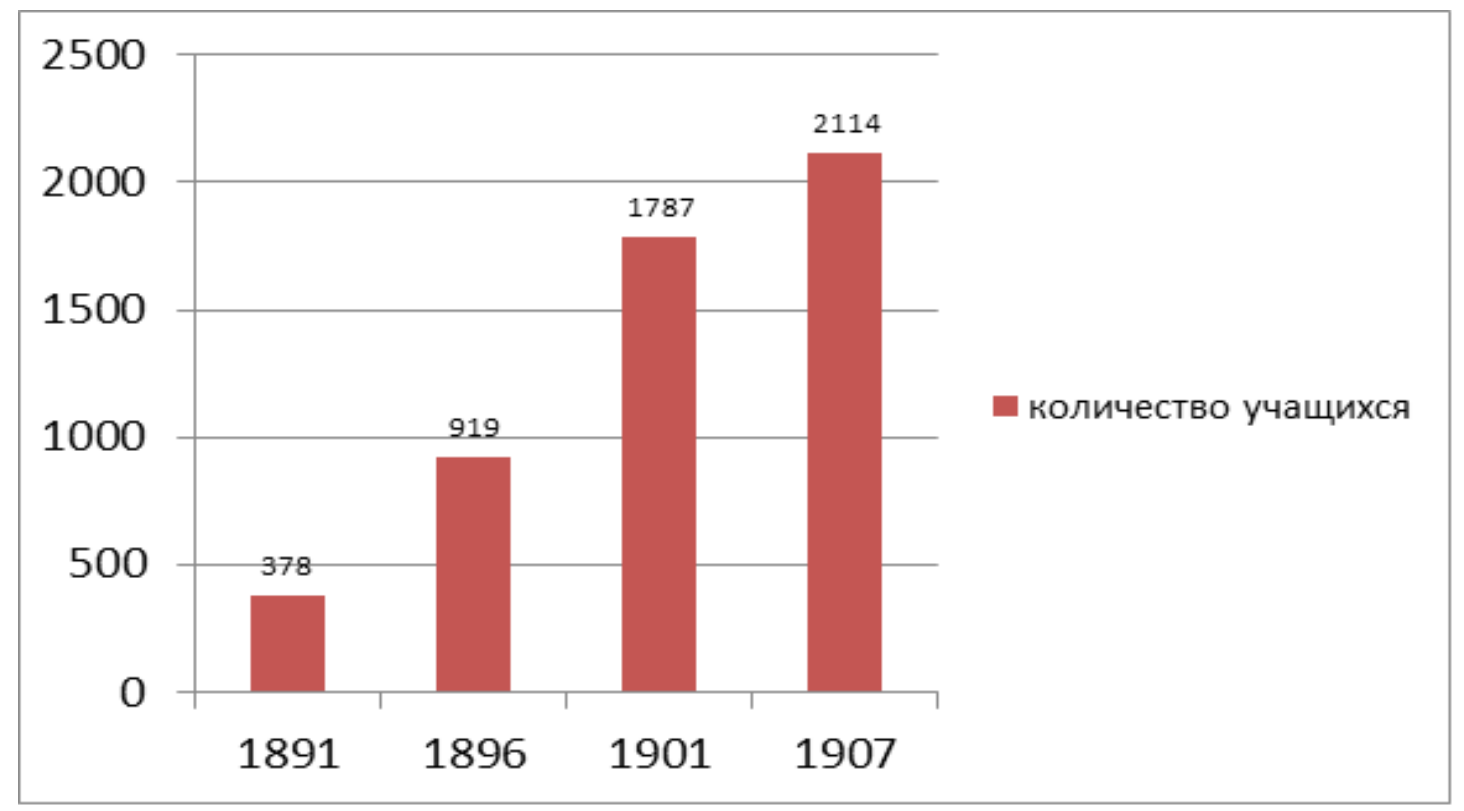

Рис. 1. Количество учащихся детей-казахов в волостных русско-киргизских школах Тургайской области

Figure 1. Number of Kazakh pupils in Russian-Kyrgyz volost schools in Turgai province 


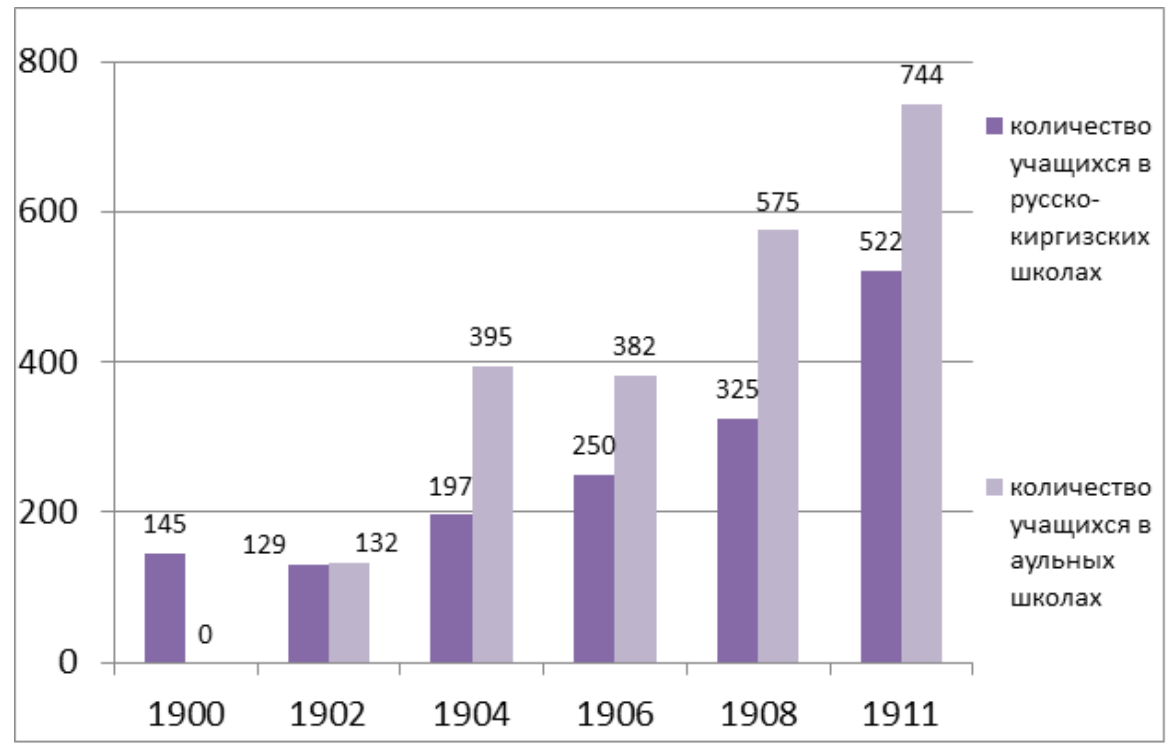

Рис. 2. Количество учащихся детей-казахов в русско-киргизских и аульных школах Семипалатинской области

Figure 2. Number of Kazakh pupils in Russian-Kyrgyz and aul schools in Semipalatinsk province

\section{Система профессионального образования}

В связи с практической необходимостью освоения аграрных и промышленных возможностей территории встал вопрос создания профессиональной системы образования. Первые попытки организации специализированных учебных заведений были сделаны в 1870-е гг., когда при низших школах и училищах открывались интернаты. Главной их целью было приобщение казахов и коренного населения Туркестана к оседлому образу жизни. При интернатах дополнительно открывали курсы ремесла для мальчиков и рукоделия для девочек. Ремесленные классы также организовывались при уездных, городских и сельских училищах. Например, в 1883 г. в Копале (Семиреченская область) при городском училище открыты столярный класс в составе 25 учеников, портняжный класс в составе 20 учеников, в двух классах из всего состава учащихся обучалось 10 казахов (Обзор Семиреченской..., 1884, c. 70).

В 1900 г. открыты ремесленные классы в Кокандском городском училище (Ферганская область) с отделениями столярного и переплетного ремесла, аналогичное учебное заведение на средства местного общества открыто в Тургайской области (Обзор Тургайской..,, 1883, с. 12-15; Обзор Ферганской..., 1901, с. 112). При каждом двухклассном русско-киргизском училище области действовало ремесленное отделение: столярное, токарное, переплетное 
(Обзор Тургайской..., 1897, с. 52). Однако вскоре такого уровня обучения стало недостаточно. Становление профессионального образования на окраинных территориях России связано с развитием социально-экономических отношений, модернизационными процессами в различных сферах, строительством железных дорог.

Начало профессиональному техническому образованию в Степном крае было положено в 1882 г. в связи с открытием Омского технического училища (с 1895 г. - императора Александра III низшее механико-техническое училище) для подготовки низших технических кадров для строительства Транссибирской железной дороги. Обучение длилось 4 года, еще 3 года занимала практика. При училище имелись квоты для казахов, которые обучались только за счет казахского общества (Айтмухамбетов, 2000, с. 109-111).

Для поступления в среднее техническое училище требовалось окончание 5-ти летнего курса реального училища или другого равного по уровню среднего учебного заведения. Поступить в низшее техническое училище могли выпускники городского, уездного или двухклассного сельского училища. Выделялись квоты на обучение за счет казахского общества. Например, в Кокчетавское техническое училище (Акмолинская область) принимали после получения начального образования, главным требованием было знание русского языка (Плахотник, 2007, с. 174-175).

В связи с присоединением территории Туркестана встала задача налаживания административного управления, всестороннего развития территории. Одним из направлений в этом и одновременно в политике модернизации стало железнодорожное строительство (Закаспийская и Ташкентская железные дороги). Это способствовало налаживанию торговых связей. Например, дорога Оренбург - Ташкент ускорила формирование специализации и товарности сельского хозяйства территории Туркестана (Бочкарева, 2019, с. 33-37).

В свою очередь, развитие сети железных дорог требовало подготовки профессиональных кадров. В России в целом создание профессиональнотехнических железнодорожных училищ происходит в 1870-е гг. в связи с железнодорожным строительством. К концу XIX в. в стране насчитывалось 42 училища. Все они входили в ведение министерства путей сообщения (Иванова, 2010, с. 129).

В 1892 г. открыто техническое училище в Асхабаде (Закаспийская область) (Обзор Закаспийской..., 1893, с. 192), в 1897 г. в нем обучался 121 ученик, в 1900 г. - 160 учеников, более 80 \% из них составляли дети железнодорожников (Обзор Закаспийской..., 1900, с. 236). К началу XX в. существенно увеличивается спрос на техническое образование, например, в Закаспийской области единственное железнодорожное училище не вмещало всех желающих получить образование. Это было связано с тем, что в Асхабаде располагалось управление Закаспийской железной дорогой, строительство которой осуществлялось 
в 1880 - начале 1890-х гг. В этой связи здесь открывается техническое и железнодорожное училища, спрос на обучение в которых был столь высок, что устанавливалась конкурсная основа приема (Обзор Закаспийской..., 1907, с. 126). Для обеспечения квалифицированными кадрами Среднеазиатской железной дороги в Сыр-Дарьинской области были открыты техническое и два железнодорожных училища, спрос на обучение в которые возрастал с каждым годом (рис. 3)

Формированию сети коммерческих и торговых училищ и классов способствовали перемены в экономике Российской империи, развитие торговых связей между регионами благодаря железнодорожному строительству и модернизации российской экономики в целом, развитию рыночных отношений, международной торговли. В целях усиления торговых связей и оборотов, в частности, вывоза хлопка и другого сельскохозяйственного сырья из Туркестана, власти стремились расширять образование в сфере торговли; так появились коммерческие училища, с 1914 г. открывались упрощенные курсы счетоводства. Представители торгово-промышленных кругов видели выгоду в получении русского образования и обучении русскому языку. В этой связи спрос на обучение в сфере коммерции возрастал.

Русское население при переселении в Туркестан в начале XX в. оседало в городах, которые становились центрами торговли; здесь и возникали учебные заведения. Поскольку население Сыр-Дарьинской области активнее других было вовлечено в торговлю за счет строительства и эксплуатации железной дороги, спрос на образование здесь был предельно высок. По данным доклада директора народных училищ Сыр-Дарьинской области С.М. Граменицкого, в 1895 г. охват русских детей школьного возраста образованием в области составлял более $60 \%$, что выше, чем во многих центральных губерниях (1896, с. 49). В Сыр-Дарьинской области с 1908 г. функционировало коммерческое училище с числом обучающихся 160 человек (Обзор СырДарьинской..., 1909, с. 68), на следующий год обучающихся было уже 270 (Обзор Сыр-Дарьинской..., 1912, с. 163).

В областном городе Акмолинской области Омске сеть коммерческих учебных заведений развивается быстрыми темпами, включает заведения разного уровня и степени подготовки. Так с 1899 г. при уездном училище открыты курсы бухгалтерии, с 1905 г. функционирует коммерческое училище, открываются торговые классы, в которых предусмотрена ускоренная подготовка кадров для торговли (Ищенко, 2011, с. 23-25), с 1912 г. начала прием торговая школа. 


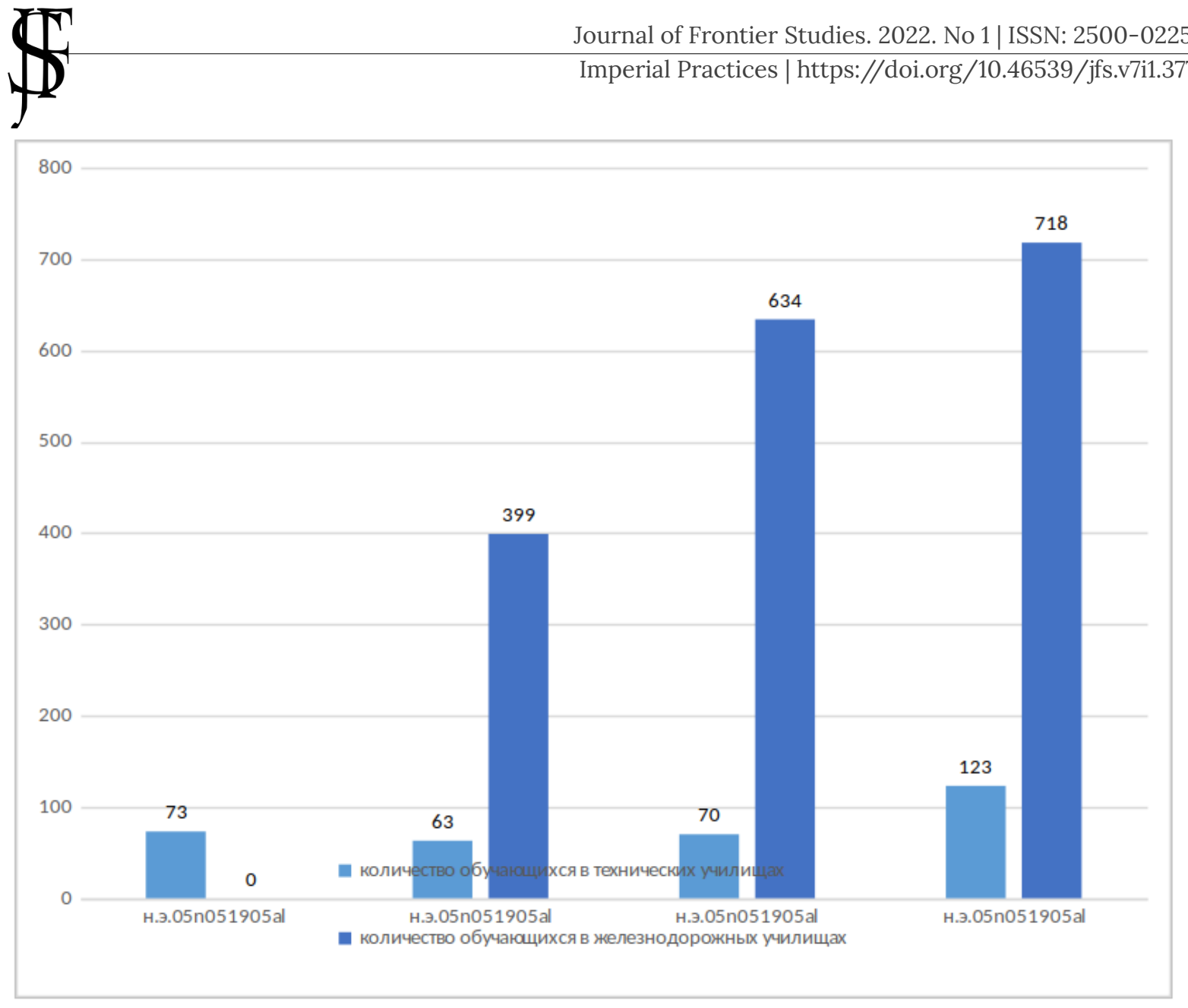

Рис. 3. Динамика количества обучающихся в технических и железнодорожных училищах Сыр-Дарьинской области

Figure 3. Dynamics of the amount of students in technical and railway schools in the Syr Darya region

Вхождение в состав Российской империи и политика интеграции в общеимперское пространство вызвали необходимость развития сельского хозяйства, выращивания хлеба на территориях, где ранее наряду с кочевым образом жизни было развито скотоводство, - прежде всего, с целью самообеспечения. К тому же Туркестан обладал крупной ресурсной базой хлопка, а на свободных территориях Степного края необходимо было осваивать пашенное земледелие.

Инородцам, до прихода на территорию русских, были незнакомы даже примитивные техники обработки земли, поэтому необходимо было создавать специальные школы, в которых можно было получить хотя бы первоначальные навыки земледелия и агрономии. Так возникают сельскохозяйственные школы, успешно функционирующие в Туркестане и Степном крае. Большая часть учебного времени в них отводилась отработке практических навыков. Школы рассматривались в качестве средства повышения знаний в области сельского 
хозяйства и, как следствие, эффективности экономической деятельности (Третьяков, 2015, с. 109).

В России система профессионального сельскохозяйственного образования сложилась в 1830-е гг. под руководством министерства государственных имуществ (Книга, 2007, с. 138). Вопрос о необходимости создания сети сельскохозяйственных школ на окраинных территориях России ставился на съезде сельских хозяев 1878 г. (Есикова, 2009, с. 150). Ускорению этого способствовали процессы модернизации, как следствие, вызвавшие разрушение замкнутости окраин, включение их в эти процессы (Южакова, 2006, с. 151).

Создание профессиональных школ стало одной из возможностей освоения сельскохозяйственных техник кочевым населением, однако учениками сельскохозяйственных школ преимущественно были русские. Школы открывались с ориентацией на возможности конкретной территории (в зависимости от почвенных и климатических условий), от этого зависел набор преподавания специальных дисциплин. Большему интересу к профессиональным учебным заведениям способствовало то, что по Положению об управлении степными областями 1891 г, казахам разрешалось иметь частные земельные участки. Однако для ведения хозяйства нужны специальные знания и навыки, которые можно было получить в сельскохозяйственных школах (Положение..., 1864, c. 124-128).

Первые сельскохозяйственные учебные заведения были созданы в 1887 г. в Семиреченской области - в Копале (16 учеников, 13 из них - из местного населения), в Караколе (11 учащихся из местного населения) и Джаркенте (15 учеников, 6 из них - из местного населения) (Обзор Семиреченской..., 1888,

c. 64-65). Каждой школе на обустройство выделено по 3 тыс. рублей из государственной казны. Самая крупная школа была в Джаркенте, в ней обучали узким направлениям: лесоводству, садоводству, пчеловодству, шелководству, а также сельскому хозяйству. При школе функционировал опытный плодовый питомник, в котором выращивалось более 600 деревьев, 460 кустов шелковицы, табак (Обзор Семиреченской..., 1901, с. 58-59). Верненское училище садоводства в конце XIX в. считалось эталоном профессиональной школы. Кроме садоводства, здесь занимались столярным и переплетным делом. В 1900 г. при школе разбит сад на 150 деревьев, построена оранжерея, в которую помещены горшечные растения, разбиты теплицы для выращивания пальм. Ученики занимались выкормкой шелковичных червей, коконы продавали в Москву (Обзор Семиреченской..., 1901, с. 64-65). Опыт деятельности сельскохозяйственных школ свидетельствует о стремлении российских властей привнести как можно больше знаний и практики в области сельского хозяйства и агрономии на территории, где еще совсем недавно население вело лишь кочевой образ жизни.

Несмотря на внедрение в школьное образование сельскохозяйственных знаний, ревизии чиновников неоднократно подчеркивали неудовлетвори- 
тельное их состояние (нехватку квалифицированных кадров, инвентаря, практических занятий) (Обзор Семиреченской..., 1902, с. 58-59).

Однако в целом успехи, несомненно, были. Транссибирская и Закаспийская железные дороги существенно ускорили темпы модернизации внутри окраинных территорий, примитивные способы, традиционно применявшиеся, в том числе в сельском хозяйстве (например, гужевые перевозки) отошли на второй план, усилилась коммерческая значимость производства (например, хлопка в Ферганской области), а также выращивание скота на экспорт в Степных областях (Бочкарева, 2019, с. 34-35). Возможности увеличения темпов перевозок делали необходимым увеличение темпов производства, как следствие, совершенствование знаний в этой области.

\section{Выводы}

Политика российских властей в области выстраивания системы образования в центральноазиатском регионе во второй половине XIX - начале XX вв. была продуманной, ориентированной на особенности развития территории, состав населения. Несмотря на предпринимаемые ограничения (открытие конфессиональных учебных заведений с разрешения областных властей, контроль над их деятельностью, штрафы за уклонение от обучения в начальных школах) образовательная политика в отношении инородческого населения характеризуется как лояльная: не происходило стремительного насаждения русского языка, русских школ. Кроме того, выстраивание системы образования было непосредственно связано с социально-экономическим развитием региона. В частности, рост торговых отношений, строительство железных дорог, постепенное формирование промышленных центров в отдельных областях региона (например, добыча угля в Самаркандской области, нефти - в Уральской), развитие сельского хозяйства способствовали формированию сети профессиональных учебных заведений. В связи с нарастающими темпами промышленного и сельскохозяйственного развития необходимо было преодолеть кадровый дефицит. Достаточно стабильно с начала XX в. начинают функционировать технические (в том числе железнодорожнотехнические учебные заведения), сельскохозяйственные школы, торговые школы разного уровня подготовки (коммерческие и торговые училища, курсы счетоводов, бухгалтерские курсы). Таким образом, отмечается непосредственная взаимосвязь модернизации социально-экономической системы центральноазиатского региона и формирования образовательной системы.

\section{Благодарности}

Исследование выполнено за счет гранта Российского научного фонда (проект №19-18-00180).

The study was supported by a grant from the Russian Science Foundation (project No. 19-18-00180). 


\section{Список литературы}

Айтмухамбетов, А. А. (2000). Народное образование и формирование Казахской интеллигенции Северо-Западного Казахстана во второй половине XIX-начале XX вв. [Диссертация ... кандидата Исторических наук: 07.00.02.]. Костанайский государственный университет.

Бекмаханова, Н. Е. (1986). Многонациональное население Казахстана и Северной Киргизии в эпоху капитализма (60-е годы XIX в. - 1917 г.). Наука.

Бендриков, К. Е. (1960). Очерки по истории народного образования в Туркестане (1865-1924). Издательство Академии педагогических наук РСФСР.

Бородкин, Л. И. (2017). Концепции модернизации и модерности в контексте российских трансформаций XIX-XX вв. Уральский исторический вестник, 4, 6-15.

Бочкарева, И. Б. (2019). Железнодорожное строительство в стратегии Российской империи по освоению Туркестана. Известия Алтайского государственного университета, 5, 33-38. https://doi.org/10.14258/izvasu(2019)5-04

Временное положение об управлении в областях Уральской, Тургайской, Аклолинской и Семипалатинской. (1883). Типография министерства внутренних дел.

Граменицкий, С. М. (1896). Очерки развития народного образования в Туркестанском крае. Типолитография торгового дома «Ф. и Г. бр. Каменские».

Доклад министра народного просвещения Д. А. Толстого «О мерах с образованием населяющих Россию инородиев». (1870). Институт национальных проблем образования - inpo-rus.ru. http://www.inpo-rus.ru/14/

Есикова, М. М. (2010). Сельскохозяйственное образование в России (вторая половина XIX-1917 гг.). Власть, 7, 150-154.

Иванова, А. Ю. (2010). Железнодорожные училища в системе образования России (вторая половина XIX в.). Наука и школа, 1, 129-130.

Инородческая школа: Сборник статей и материалов по вопросам инородческой иколы. (1916). Типография Н.П. Карбасникова.

Ищенко, О. В. (2011). Развитие общего и профессионального образования В Западной Сибири во второй половине XIX - начале XX века. Вестник Томского государственного педагогического университета, 13, 22-28.

Кауфман, К. П. (1885). Проект всеподданнейшего отчета ген.-адъютанта К.П. Кауфмана по гражданскому управлению и устройству в областях Туркестанского генерал-губернаторства: 7 ноября 1867 - 25 марта 1881. Издательство Воен.-учен. Ком. Гл. штаба.

Книга, М. Д. (2007). Становление сельскохозяйственного образования в России в XIX в. Вестник Саратовского государственного социально-экономического университета, 18, 137-141.

Ковальченко, И. Д. (1959). Динамика уровня земледельческого производства России в первой половине XIX в. История СССР, 1, 53-86.

Котюкова, Т. В. (2015). Туркестан в дискурсе фронтирной модернизации Российской империи в конце XIX-начале XX в. Ислам в современном мире: внутригосударственный и международно-политический аспекты, 11(1), 43-54.

Литвак, Б. Г. (1976). О достоверности сведений губернаторских отчетов XIX в. В Источниковедение отечественной истории (сс. 125-144). Наука.

Лысенко, Ю. А. (2011). Очерки истории Русской православной церкви в Казахстане (XVIII - начало $\mathrm{XX}$ в.). Азбука.

Лысенко, Ю. А., Анисимова, И. В., Тарасова, Е. В., \& Стурова, М. В. (2014). Традиционное казахское общество в национальной политике Российской илперии: Концептуальные основы $и$ механизмы реализаиии (XIX-начало XX в.). Алтайский государственный университет.

Лысенко, Ю. А., Рыгалова, М. В., \& Егоренкова, Е. Н. (2021). Русский язык как механизм интеграции Степного генерал-губернаторства России в общеимперское пространство 
(вторая половина XIX-начало XX в.). Вестник археологии, антропологии и этнографии, 1, 154-163. https://doi.org/10.20874/2071-0437-2021-52-1-14

Любичанковский, С. В. (2018). Русский язык как средство аккультурации: Развитие русскоинородческих школ в Оренбургском крае в середине XIX века. Самарский научный вестник, 7(1), 161-165.

Обзор Акмолинской области за 1889 год. (1890). Типография Акмолинского областного правления.

Обзор Закаспийской области за 1892 год. (1893). Типография Закаспийского областного статистического комитета.

Обзор Закаспийской области за 1898 год. (1900). Типография Закаспийского областного статистического комитета.

Обзор Закаспийской области за 1905 год. (1907). Типография Закаспийского областного статистического комитета.

Обзор Семиреченской области за 1883 год. (1884). Типография Семиреченского областного правления.

Обзор Семиреченской области за 1887 год. (1888). Типография Семиреченского областного правления.

Обзор Семиреченской области за 1901 год. (1902). Типография Семиреченского областного правления.

Обзор Сыр-Дарьинской области за 1908 год. (1909). Типография при канцелярии Туркестанского Генерал-губернатора.

Обзор Сыр-Дарьинской области за 1910 год. (1912). Типография при канцелярии Туркестанского Генерал-губернатора.

Обзор Тургайской области за 1878 год. (1879). Типография Б. Бреслина.

Обзор Тургайской области за 1882 год. (1883). Типография Б. Бреслина.

Обзор Тургайской области за 1896 год. (1897). Типография Б. Бреслина.

Обзор Ферганской области за 1900 год. (1901). Типография Ферганского областного правления.

Отчет о состоянии Омской епархии за 1902 г. (2014). В Традиционное казахское общество в национальной политике Российской илперии: Конщептуальные основы и механизмы реализации (XIX-начало XX в.). Документы и извлечения (сс. 449-456). Азбука.

Плахотник, Т. Ю. (2007). Деятельность администрации Степного края в сфере начального образования казахского населения в конще XIX - начале XX вв. [Диссертация... кандидата исторических наук]. Омский государственный университет.

Положение о начальных народных училищах, 19 июля 1864 г. (1867). В Полное собрание законов Российской илперии. Собрание 2. 39, 1.41068 (сс. 613-618). Типография II Отделения Собственной Его Императорского Величия Канцелярии.

Правила о церковно-приходских школах, 13 июня 1884 г. (1884). В Полное собрание законов Российской империи. Собрание 3, 4, 2318 (сс. 372-374). Государственная типография.

Третьяков, А. В. (2015). Формирование системы сельскохозяйственного образования в России второй половины XIX-начала XX вв. Научные ведомости Белгородского государственного университета. Серия: История. Политология, 13, 103-110.

Туркестанские ведомости. (1898). 73.

Ремнев, А., \& Суворова, Н. (2013). Управление миграционными процессами в позднеимперской России: Концепты, люди и структуры. В Местные сообщества, местная власть и мигранты в Сибири на рубежах XIX-XX и XX-XXI веков (сс. 27-92). Наука.

Шабунова, А., Соловьева, Т., Гулин, К., \& Ласточкина, М. (2012). Модернизащия экономики региона: Социокультурные аспекты. ИСЭРТ РАН.

Южакова, Т. Л. (2006). Динамика, состав и расселение русского сельского населения Степного края во второй половине XIX-начале XX в. Вестник Оренбургского государственного университета, 9, 151-158. 


\section{References}

Aitmukhambetov, A. A. (2000). Folk education and the formation of the Kazakh intelligentsia of NorthWestern Kazakhstan in the second half of the 19th and early 20th centuries. [Dissertation ... $\mathrm{PhD}$ in History]. Kostanay State University. (In Russian).

Bekmakhanova, N. E. (1986). The Multinational Population of Kazakhstan and Northern Kyrgyzstan in the Age of Capitalism (1960s-1917). Nauka. (In Russian).

Bendrikov, K. E. (1960). Essays on the history of public education in Turkestan (1865-1924). Academy of Pedagogical Sciences of the RSFSR. (In Russian).

Bochkareva, I. B. (2019). Railway construction in the Russian Empire's strategy for the development of Turkestan. Izvestia of Altai State University, 5, 33-38. https://doi.org/10.14258/izvasu(2019)5$\underline{04}$ (In Russian).

Borodkin, L. I. (2017). Concepts of Modernization and Modernity in the Context of Russian Transformations of the 19th-20th Centuries. Ural Historical Herald, 4, 6-15. (In Russian).

Esikova, M. M. (2010). Agricultural Education in Russia (second half of the 19th century-1917). Vlast, 7 , 150-154. (In Russian).

Foreign School: A Collection of Articles and Materials on Foreign School Issues. (1916). Printing house of N.P. Karbasnikov. (In Russian).

Gramenicki, S. M. (1896). Sketches of the development of public education in Turkestan province. Lithography of the trading house "F. and G. Brothers. Kamensky". (In Russian).

Ishchenko, O. V. (2011). Development of General and Vocational Education in Western Siberia in the Second Half of the 19th and the Early 20th Centuries. Bulletin of Tomsk State Pedagogical University, 13, 22-28. (In Russian).

Ivanova, A. Y. (2010). Railway schools in the Russian educational system (second half of the $19^{\text {th }}$ century). Science and school, 1, 129-130. (In Russian).

Kaufman, K. P. (1885). Draft report of Adjutant General K.P. Kaufman on civil administration and organization in the regions of Turkestan Governorate General: 7 November 1867 - 25 March 1881. Publishing house of the Military Scientific Society. Com. Chief of Staff. (In Russian).

Kniga, M. D. (2007). The emergence of agricultural education in Russia in the 19th century. Bulletin of Saratov State Social and Economic University, 18, 137-141. (In Russian).

Kotiukova, T. V. (2015). Turkestan in the discourse of frontier modernisation of the Russian Empire in the late 19th and early 20th centuries. Islam in the Modern World: Domestic and International Political Aspects, 11(1), 43-54. (In Russian).

Kovalchenko, I. D. (1959). Dynamics of the level of land production in Russia in the first half of the $19^{\text {th }}$ century. History of the USSR, 1, 53-86. (In Russian).

Litvak, B. G. (1976). On the reliability of the information in the 19th century governor's reports. In Source study of Russian history (pp. 125-144). Nauka. (In Russian).

Lubichankovsky, S. V. (2018). Russian Language as a Means of Acculturation: Development of RussianIndigenous Schools in the Orenburg Region in the Mid-19th Century. Samara Scientific Bulletin, 7(1), 161-165. (In Russian).

Lysenko, Y. A. (2011). Essays on the History of the Russian Orthodox Church in Kazakhstan (18th early 20th century). Azbuka. (In Russian). 
Lysenko, Y. A., Anisimova, I. V., Tarasova, E. V., \& Sturova, M. V. (2014). Traditional Kazakh Society in the National Policy of the Russian Empire: Conceptual Foundations and Mechanisms of Implementation (19th - early 20th century). Altai State University. (In Russian).

Lysenko, Y. A., Rygalova, M. V., \& Yeogorenkova, E. N. (2021). The Russian language as a mechanism of integration of the Russian Steppe Governorate General into the Imperial space (second half of the 19th century - beginning of the 20th century). Bulletin of Archaeology, Anthropology and Ethnography, 1, 154-163. https://doi.org/10.20874/2071-0437-2021-52-1-14 (In Russian).

Overview of the Akmola region for 1889. (1890). Printing house of Akmola regional board. (In Russian).

Overview of the Ferghana region for 1900. (1901). Printing house of the Fergana Provincial Board. (In Russian).

Overview of the Semirechensk region for 1883. (1884). Printing house of the Semirechensk Regional Board. (In Russian).

Overview of the Semirechensk region for 1887. (1888). Printing house of the Semirechensk Regional Board. (In Russian).

Overview of the Semirechensk region for 1901. (1902). Printing house of the Semirechensk Regional Board. (In Russian).

Overview of the Syr Darya region for 1908. (1909). Printing office of the Governor General of Turkestan. (In Russian).

Overview of the Syr Darya region for 1910. (1912). Printing office of the Governor General of Turkestan. (In Russian).

Overview of the Trans-Caspian region for 1892. (1893). Printing house of the Trans-Caspian Regional Statistical Committee. (In Russian).

Overview of the Trans-Caspian region for 1898. (1900). Printing house of the Trans-Caspian Regional Statistical Committee. (In Russian).

Overview of the Trans-Caspian region for 1905. (1907). Printing house of the Trans-Caspian Regional Statistical Committee. (In Russian).

Overview of the Turgai region for 1878. (1879). B. Breslin's printing house. (In Russian).

Overview of the Turgai region for 1882. (1883). B. Breslin's printing house. (In Russian).

Overview of the Turgai region for 1896. (1897). B. Breslin's printing house. (In Russian).

Plakhotnik, T. Yu. (2007). Activities of Steppe Krai administration in the sphere of primary education of Kazakh population in the late 19th - early 20th centuries. [Dissertation... PhD. in History]. Omsk State University. (In Russian).

Provisional Regulation on Governance in the Urals, Turgai, Akmola and Semipalatinsk Provinces. (1883). Printing house of the Ministry of the Interior. (In Russian).

Regulation on Primary Public Schools, 19 July 1864. (1867). In Complete Collection of Laws of the Russian Empire. Collection 2. 39, 1. 41068 (pp. 613-618). Printing Office II of His Imperial Majesty's Own Chancellery. (In Russian).

Regulations on parochial schools, 13 June 1884. (1884). In Complete Collection of Laws of the Russian Empire. Collection 3, 4, 2318 (pp. 372-374). Government printing house. (In Russian).

Remnev, A., \& Suvorova, N. (2013). Managing Migration Processes in Late Imperial Russia: Concepts, People and Structures. In Local communities, local government and migrants in Siberia at the turn of the 19th-20th and 20th-21st centuries (pp. 27-92). Nauka. (In Russian).

Report of the Minister of National Education D.A. Tolstoy "On Measures for the Education of the NonRussian Population in Russia". (1870). Institute of National Education Issues - inpo-rus.ru. http://www.inpo-rus.ru/14/ (In Russian). 
Report on the state of the Omsk diocese for 1902. (2014). In Traditional Kazakh Society in the National Policy of the Russian Empire: Conceptual Foundations and Mechanisms of Implementation (19th-early 20th centuries). Documents and extracts (pp. 449-456). Azbuka. (In Russian).

Shabunova, A., Solovyova, T., Gulin, K., \& Lastochkina, M. (2012). Modernising the regional economy: Socio-cultural aspects. ISEDT RAS. (In Russian).

Tretiakov, A. V. (2015). Formation of Agricultural Education System in Russia in the Second Half of the 19th and Early 20th Centuries. Scientific journal of Belgorod State University. Series: History. Political Science, 13, 103-110. (In Russian).

Turkestan Gazette. (1898). 73. (In Russian).

Yuzhakova, T. L. (2006). Dynamics, composition and resettlement of Russian rural population in the Steppe region in the second half of the 19th and the beginning of the 20th centuries. Bulletin of the Orenburg State University, 9, 151-158. (In Russian). 